\title{
Drones and Possibilities of Their Using
}

\author{
Piotr Kardasz ${ }^{1 *}$, Jacek Doskocz ${ }^{1}$, Mateusz Hejduk², Paweł Wiejkut ${ }^{3}$ and Hubert Zarzycki ${ }^{4}$ \\ ${ }^{1}$ Klaster B+R\&I ul. Piłsudskiego Wrocław, Poland \\ ${ }^{2}$ International University of Logistics and Transport in Wroclaw, ul. Soltysowicka, Wrocław, Poland \\ ${ }^{3}$ Lower Silesia Accelerator Technology and Innovation Sp z o.o., ul. Nowodworska, Wrocław, Poland \\ ${ }^{4}$ Wyższa Szkoła Informatyki Stosowanej we Wrocławiu, Wrocław, Poland
}

\begin{abstract}
This article shows the drones and possibilities of their using. First there was discussed construction of the drone, which the most important elements are frame, propellers, engine, system of power the electronic control and communication system. A drone is powered by batteries, which is the major drawback, because it is exhausted after 15 minutes of flight, causing a decrease drone on the ground. The lithium-polymer batteries are used for powering the drones. Then there were compared the military and civilian drones on selected examples. Military drones differ from civil of size and drive. They are bigger and powered by internal combustion engines. Civil drones are driven by electric motors. Next there were shown the possibilities of using the drones. They can be used by the public services (like police, fire brigades, border guards), by army, in industry, for taking photos and filming, in delivering shipments. The article shows the danger connecting with using the drones. The main danger of using the drones is the fall of a drone from a great height, which may be due discharge of the battery, damage caused by weather conditions (low air temperature, precipitation), hitting in an obstacle (tree, building, high-voltage line). Currently a lot of projects related to the development of power for drones are conducted like battery of grapheme, pure lithium anodes, and fuel cells. A very important risks associated with the extensive use of civilian drones is related with privacy and the rights of citizens.
\end{abstract}

Keywords: Civil drones; Construction; Drones; Lithium-polymers accumulators; Military drones; Risk assessment

\section{Introduction}

Drones or Unmanned Aerial Systems (UAV - Unmanned Aerial Vehicle or UAS - Unmanned Aerial Systems) are the aircrafts, which are able to fly without a pilot and passengers on board. Drone Controlling is performed remotely by radio waves or autonomously (with a predetermined route). Drones do not have a specific size or type of a drive. They are often equipped with accessories used for surveillance and monitoring, in the form of the optoelectronic heads. The most important feature of the drones is that they do not need any additional infrastructure to quickly register and monitor a designated area or object. A significant advantage is the extremely short reaction time when it comes to commissioning and preparing the unit for a flight. The precursors of UAVs are aircrafts used primarily in the uniformed services - the army and the police. The first countries that started researches on UAVs were the United States, the United Kingdom, Russia, Germany and Israel. The first time an unmanned flying vehicle was used by the Austrians in August of 1849. At the time there were used the balloons (filled with explosives) which have been known for almost 150 years and which were be used as bombs [1]. One of the first creators of drones was Charles Kettering, who in collaboration with Elmer Sperrym, Orville Wright and Robert Milikanem created in 1915, the aircraft named "Kettering Bug". It was a primitive automatic plane, which on the basis of sensors defined its height (by using a barometer), the distance traveled (based on the amount of engine spins) and the position [2]. In contrast, the first civilian aircraft was produced only in the 80s of the twentieth century in Japan at the request of the Minister of Agriculture, Forests and Fisheries [3]. Public drones differ from military in the size and the drive. They are smaller and they are driven by an electric motor (military are driven by an internal combustion engine). They are mainly used for photographing and filming [4].

\section{Drone construction}

Drone is composed of two major systems:

1. Movement system

2. Control system.

\section{Movement system}

Frame: The basic element of a drone is a frame, which should be maximum light. The classification of frame construction is mainly based on the number of arms. The possible solutions of frames construction are shown in Figure 1. Due to the number of arms and the motors used the drones can be divided into:

1. Bicopters - two engines,

2. Tricopters - three engines,

3. Quadrocopters - four engines,

4. Hexacopters - six engines,

5. Octocopters - eight engines.

It is generally recognized that the construction with more arms allows for a more stable flight. The frame is made of carbon cloth $3 \mathrm{~K}$.

Propellers and engine: The next components of a drone are engine and propellers. They constitute the main propulsion system of a drone and are subjected to the highest loads, therefore their durability is very important. The propellers change a torque (derived from the engine) for a work used for lifting the vehicle in the air [5]. Due to the propeller system in relation to the flight direction it can be divided into the following types:

1. + - One is the leading propeller (at least four propellers),

2. $\mathrm{X}$ - The most common construction, in which two propellers are leading (with an even number of propellers),

*Corresponding author: Piotr Kardasz, Klaster B+R\&I ul. Piłsudskiego 74, 50-020 Wrocław, Poland, Tel: +48 668419 147; E-mail: p.kardasz@klasterbri.pl

Received March 14, 2016; Accepted March 17, 2016; Published March 19, 2016

Citation: Kardasz P, Doskocz J, Hejduk M, Wiejkut P, Zarzycki H (2016) Drones and Possibilities of Their Using. J Civil Environ Eng 6: 233. doi:10.4172/2165784X.1000233

Copyright: $\odot 2016$ Kardasz $P$, et al. This is an open-access article distributed under the terms of the Creative Commons Attribution License, which permits unrestricted use, distribution, and reproduction in any medium, provided the original author and source are credited. 

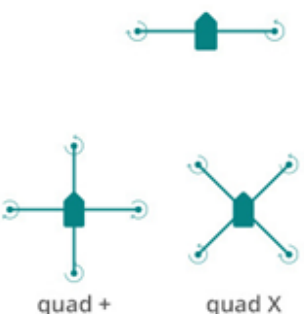

quad $\mathrm{X}$
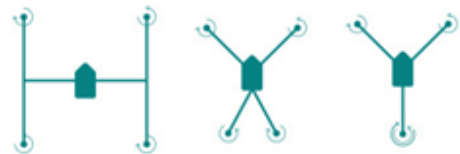

Quad V

Quad Y
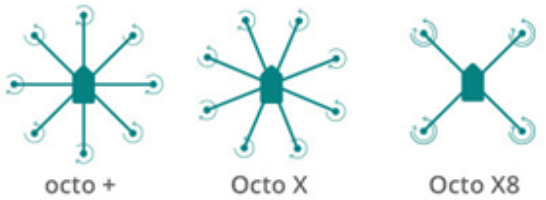

Octo X8
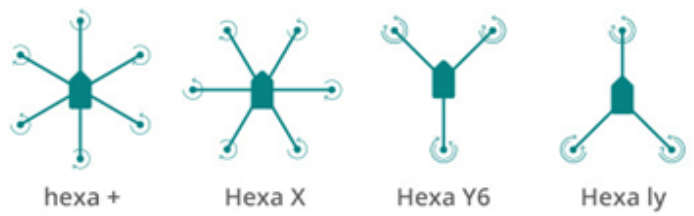

Figure 1: Possible solutions of frame construction.

3. $\mathrm{Y}$ - Three arms stacked in the $\mathrm{Y}$, where one or two arms can be leading,

4. V - Very rare arrangement in which two propellers lead onto outstretched arms,

5. $\mathrm{H}-\mathrm{A}$ very rare arrangement where the construction is based on the $\mathrm{H}$-shaped with two propellers leading.

In each of the above-mentioned construction can be mounted double propellers (at the top and in the bottom), which significantly increases the strength of the drone, and does not require the addition of another arm. Double propellers mounted on a smaller number of arms increases the strength of a drone allowing more lift capacity and insuring the parallel engine in case of a failure. Thus, the own weight of multicopter is reduced, the material costs are falling and the drone can carry a heavier load. The double propellers rotate in opposite directions, balancing one other the inertia force. The wings of drones can be divided also on adapted for rotation:

1. Clockwise $(\mathrm{CW})$,

2. Counter Clock Wise (CCW) [5].

The wings are made of carbon fiber, plastic or aluminum, and are attached to each other by lamination (also used for attaching the drone extremities), which ensures optimum performance between the weight of the entire construction and mechanical durability [5]. Because of the engine and propellers must be replaced as their consumption, the periodic preventive inspections are carried out. The size of the wings is very important. The larger is the diameter; the lower is the speed, which contributes to a reduction of drone volatility. The larger the wing blades, the greater aerodynamic lift generated, also the pressure exerted on the propeller hub also increases and the forces deforming propellers are getting bigger. The bigger are the propeller blades the stronger must also be the engine to cope torque, which is required to propel propellers, into motion. In addition, it is important to balance each propeller before use to minimize vibrations generated by the unequal operation of the system. It is very important to choose the engine and propellers in such a way that drones could for as long as possible to lift a given load (Figure 2).

The brush engines are used very often for building drones. However, the experiences have shown [5] that using brushless motors improves durability, efficiency and reduces the consumption of moving parts. This allows for longer and less emergency work of the engines.

The power of a drone: The residence time of the object flying in the air depends both on the type of drive and the type of power supply [6]. A drone is powered by batteries, which is the major drawback, because it is exhausted after 15 minutes of flight, causing a decrease drone on the ground. In general, batteries are the sets of two or more voltaic cells of the same type, providing a current that is stronger than a single cell. These can be divided into disposable batteries and electric accumulators that can be unloaded and loaded many times. In the batteries and accumulators complex chemical reactions occur in which, depending on the type of battery participates many chemical elements. As a result of chemical reactions the chemical energy contained in their active substances is converted into electrical energy. Batteries are defined as chemical current sources. The set of active substances and the electrolyte is the basis of chemical current sources action. This set functions in the form of a cell containing positive and negative electrodes and an electrolyte in individual sealed enclosure in the batteries and accumulators [7].

The cells are a source of direct current and in depending on the type of chemical reaction can be divided into:

1. Primary cells in which electricity generation followed by an irreversible chemical reaction.

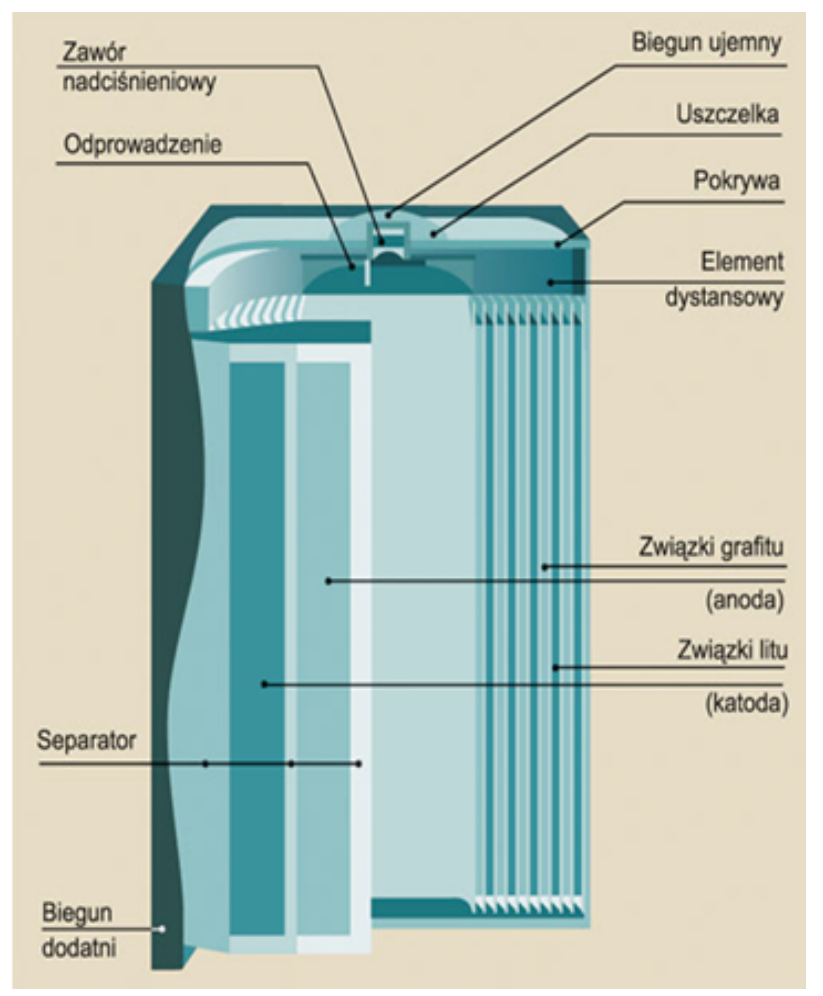

Figure 2: Construction of a lithium-polymer battery. 
2. They are not designed to be charged by any other electricity source.

3. Secondary cells in which electricity generation occurs by reversible chemical reaction and are designed to be charged by other electricity sources. The battery is a source of electrical energy generated by direct transformation of chemical energy, which consists of one or more primary cells which is not reusable, including the housing, the ends and marking. Accumulator (electric) is a chemical power source allowing the multiple storage and release of electricity as a result of reversible transformations of energy. This is a source of electrical energy generated by direct transformation of chemical energy, which consists of one or more secondary reusable cells [7].

The various kinds of bacteria and accumulators are used currently. The following battery can be distinguished:

1. Zinc-carbon (zinc-manganese with chloride electrolyte),

2. Zinc-mercury,

3. Silver-zinc,

4. Alkaline (manganese-zinc with alkaline electrolyte),

5. Lithium. To the lithium batteries include a lot of subtypes, which combines the use of lithium or its compounds as anodes. Among the compounds used on the cathode include minibars and safes manganese oxide (IV), thionyl chloride, sulfur oxide (IV), iodine, chromate (VI), silver and others.

Among accumulators are used:

1. Lead-acid,

2. Lithium-ion,

3. Nickel-iron,

4. Nickel-cadmium,

5. Nickel-zinc,

6. Nickel-metal-hydride,

7. Silver-zinc,

8. Zinc-air,

9. Lithium-polymer.

The lithium-polymer batteries are used for powering the drones. They differ from them only some properties and parameters. The basic principle of operation, as well as the chemical reactions occurring in the cell is the same as in Li-ion cells. In the Li-ion cells the one of the electrodes is made of porous carbon and the second of metal oxides. The role of the electrolyte fulfills here complex lithium salts dissolved in a mixture of organic solvents. The most commonly used material for the cathode is $\mathrm{LiCo}_{2}$. In this type of accumulators the following reactions occur:

$$
\begin{aligned}
& \mathrm{LiMO}_{2} \rightarrow \mathrm{Li}_{1-\mathrm{x}} \mathrm{MO}_{2}+\mathrm{xLi}^{+}+\mathrm{xE} \\
& \mathrm{xLi}^{+}+\mathrm{xe}^{-}+\mathrm{C} \rightarrow \mathrm{Li}_{\mathrm{x}} \mathrm{C} \\
& \text { where, } \mathrm{M}=\mathrm{Ni}, \mathrm{Co}, \mathrm{Mn}
\end{aligned}
$$

A positive electrode constitute the metal-oxides of lithium, $\mathrm{Li}_{\mathrm{X}} \mathrm{Mn}_{2} \mathrm{O}_{4}, \mathrm{Li}_{\mathrm{X}} \mathrm{CoO}_{2}, \mathrm{Li}_{\mathrm{X}} \mathrm{NiO}_{2}$, the mixture of $\mathrm{MnO}_{2} \mathrm{i} \mathrm{Li}_{2} \mathrm{MnO}_{3}$. A negative electrode constitutes a special graphite or electrode made on the basis of amorphous tin oxide, and also are used the alloys of $\mathrm{Li}$ -
$\mathrm{Al}, \mathrm{Li}-\mathrm{Si}, \mathrm{Li}_{4} \mathrm{Ti}_{5} \mathrm{O}_{12}$. The electrolyte is a lithium salt dissolved in organic solvents means (lithium perchlorate $\left(\mathrm{LiClO}_{4}\right)$, dioxolane $\left(\mathrm{C}_{3} \mathrm{H}_{6} \mathrm{O}_{2}\right)$ ). This type of accumulators discharge at a slower rate than the devices using nickel and it is also lighter of them. The voltage obtained from them is higher. Lithium-ion accumulators must be recharged frequently, and immediately after unloading (in contrast to nickel accumulators). It is necessary to keep them in a cool place, because high temperatures can cause a decrease of their viability and in extreme cases an explosion of the battery. Li-ion cells have a relatively high operating voltage, containing in the range $4.1-2.5 \mathrm{~V}$, while their nominal voltage is $3.6 \mathrm{~V}$. The proper energy of commercially available Li-ion batteries is more than $150 \mathrm{Wh} / \mathrm{kg}$. The maximum discharge currents may reach up to $5 \mathrm{C}$, although in most cases it is not recommended to exceed the loads 1-2C. Coefficient of self-discharge of Li-ion battery is very small and they can be stored for several years without significant loss of capacity. They did not show a memory effect, and the temperature range in which they may work is extremely wide and range from -40 to $65^{\circ} \mathrm{C}$ [6]. From the user's perspective, Li-Po cells differ from $\mathrm{Li}$-ion cells of the rated voltage (it amounts $3.7 \mathrm{~V}$ ) and maximum $(4.2 \mathrm{~V})$. During using the batteries it is necessary to pay attention, that not to exceed the lowest $(3 \mathrm{~V})$ and the highest $(4.2 \mathrm{~V})$ allowed voltage on the targets. Characteristics of using the battery is non-linear, so the charging and discharging currents should not be exceeded. In addition, Li-Po cells have a higher resistance to mechanical damage than Li-ion, and they can work at much higher loads-up to 30C, depending on the cell type [6]. These batteries, unlike the conventional lithium-ion batteries with liquid electrolytes, use electrolyte in solid form, in which the essential components is the polymer with a lithium salt dissolved in it. The use of solid polymer increases the resistance of cells in the case of short circuit or overcharging and eliminates the problem of possible an electrolyte leakage, which significantly increases the safety of using these accumulators. For the lithium-polymer accumulators construction are used the lithium metal alloys and conductive polymers. Due to the presence of polymers the new technology enables the construction of flexible, very thin and flat flexible cells (even about millimeter thickness). However these cells are not resistant and easily damaged by even a small overcharging, so electronic circuitry controlling the charging process are very complex. The accumulators have a high energy density and relatively high degree of flexibility in the design of shapes and sizes. To ensure emergency-free and safe operation the accumulators or accumulators packs (series of cells) must be equipped with an electronic battery management system BMS. Due to the extremely favorable ratio of volume to weight ratio and minimal self-discharge they are a very attractive a power source in model building $[7,8]$. Classic electrochemical accumulators, despite the increase of their specific energy in recent years do not provide the basic requirement, which is a long residence time of a drone in the air [6] From the user's perspective, used electrochemical accumulators should be characterized by:

1. Small sizes,

2. Small mass,

3. Fast loading time,

4. High safety of using,

5. High durability,

6. Negligible phenomenon of self-discharge,

7. Low price.

The above features make, that at the possible smallest volume, at 
the possible low weight we can obtain a source of electricity with high energetic efficiency. And the possibility for fast charging allows in a short time supplement the energy in the accumulator [6].

\section{The electronic control and communication system}

The control system is responsible for the drone fly up, down; rotate, for his reaction to the emerging forces and for stability. Most of the control systems are equipped with the same set of sensors with the difference in the speed of calculations and in algorithms used. The control system consists of [4]:

1. Flight controller, responsible for machine control capabilities,

2. ESC (Electronic Speed Control) -the unit responsible for engine $\mathrm{rpm}$,

3. Supplying plate, separating the power supply for regulators turnovers and motors,

4. Sim module, which allows the transmission of telemetry data,

5. Proximity camera - an element of anti-collision system,

6. The numeric keypad to enter the customer PIN codes.

Controllers engines are used to ensure maximum performance and the highest level of fail safety. Controls should be selected, so that their parameters correspond to the maximum current consumption of the motor, which shall ensure the maximal parameters of drives. Some controllers have additional exit type BEC (Battery Eliminator Circuits), thus it is possible to supply the control system with the voltage of $5 \mathrm{~V}$ and efficiency of 2A [9-13]. This provides good working conditions of control system. Limited is also the complexity of the control board. The controller also controls the condition of the battery. When the battery voltage drops to low levels, it forces a reduction in engine RPM, preventing the damage of battery. It provides additional security when the control unit will not work. Programming the controllers is carried out using a programming card, thanks to which it is possible to change the parameters of the devices - the voltage level of a power cut, and how to start up the engine [5]. During the designing process of the control system must first pay attention to the correct power to the controller and establishing communication by the programmer. In a further step it is needed to include the necessary filtration power (capacitors and choke) and protection of the pin analog-to-digital converter. The digital transducer serves as a voltage meter and its conversion into digital form, understandable for the controller. By measuring the voltage at every cell we can gain information about the battery charge [5]. In study [5] for controlling the motor rotary speed was used a mechanism PWM (Pulse Width Modulation) or pulse width modulation. It is possible using this method to obtain different average voltage. At this project we use Bluetooth communication between the controller and smartphone with Android operating system [5]. Android is now the most popular operating system in the world for mobile devices. It is distinguished by openness, small hardware requirements, simple configuration and easy transfer between different mobile devices. This has contributed to the preparation of an application that allows controlling the drone from the level of smartphone. This allows for data transmission up to $100 \mathrm{~m}$. To start flights control unit must know the location of the machine in space, which allows the measurement module, containing a gyroscope and accelerometer, which communicates with the controller via the $\mathrm{I} 2 \mathrm{C}$ bus. The gyroscope allows tracking the flight of the object, and accelerometer allows the drift of the module and determines the absolute point of reference. Drone control is done by varying the speed of the respective motors. The control algorithm is necessary to stabilize the machine in air. Comparison of military and civilian drones on selected examples.
Military drones differ from civil of size and drive. They are bigger and powered by internal combustion engines. Civil drones are driven by electric motors [14-19].

Civil drones: One example is the DJI Phantom Vision 2, which is used for photography and video filming. The mass of the airplane battery is $1160 \mathrm{~g}$. A lithium-polymer cell with a capacity of $5200 \mathrm{mAh}$ for driving the four rotors allows for 25 minutes of continuous flightwith with the recording. The control is performed over the air waves with a frequency of $5.8 \mathrm{GHz}$ using the remote control. The effective control range is $300 \mathrm{~m}$, and using signal amplifiers even $1000 \mathrm{~m}$. Thanks to the Wi-Fi module the synchronization the device with a phone or tablet is possible, which increases the possibility of modifying settings for drone in flight, such as the size or resolution of the recording multimedia, information about the status of the machine (battery status, connection to GPS altitude speed). It is also possible the preview of the camera view "live", recording and downloading videos and photos during the flight. The GPS receiver with software provides a standalone return to the starting point in case of losing the connection with the controller. Drone also recognizes areas, where flights are prohibited (proximity to the airport) and inform the controller about it. The heart of the drone is a camera with photos resolution of 14 Megapixels, filming of $1080 \mathrm{p}$, diagonal of the matrix $1 / 2.3$ " and the field of view of $110^{\circ} / 85^{\circ}$. Photos are saved in formats .JPEG and .RAW, which facilitates their interpretation. After equipping the drone with a camera of different type and the appropriate software, the camera can be used to map areas difficult to access [4].

Military drones: An example of the military drones is MQ-1 Predator ( $\mathrm{M}$ - is a multirole aircraft, $\mathrm{Q}$ mark the drones), which belongs to the UCAV (Unmanned Combat Aerial Vehicle). In the apparatus emphasis is placed on tools for observation. There was used the cameras with a very high resolution, thermal imaging and the infrared. Components of the drone are as follows:

1. Rotax four-cylinder engine with 115 horsepower,

2. Communications antenna Ku-band,

3. Two internal GPS antenna and GPS navigation system,

4. Sets of fuel cells,

5. Set of cameras and encoders,

6. Transmitter, receiver and radar antenna slot.

- It is part of the whole set which includes:

1. Four drones type of RQ-1 or MQ-1,

2. Ground control station usually placed on a truck, which housed the position of the pilot, the operator of sensors or weapons and an antenna with a diameter of $6.1 \mathrm{M}$ with accessories.

This enables communication between drones and ground control station. The advantage of predators is their easy transport, because they can be disassembled into six parts [4].

Comparision of the drones: Table 1 describes the comparison of the two types of drones.

\section{Specifications and possibilities of using drones}

\section{Legal regulations}

Polish law very little said about drones. The act "Aviation Law" of the 30 June 2011 tells about the "model aircrafts and unmanned aerial 
Citation: Kardasz P, Doskocz J, Hejduk M, Wiejkut P, Zarzycki H (2016) Drones and Possibilities of Their Using. J Civil Environ Eng 6: 233. doi:10.4172/2165-784X.1000233

\begin{tabular}{|c|c|c|}
\hline Feature & DJI Phantom View 2 & GAAS MQ-1 \\
\hline $\begin{array}{l}\text { Size (length } \mathrm{x} \text { width } \mathrm{x} \\
\text { height) }\end{array}$ & $0.29 \times 0.29 \times 0.18 \mathrm{~m}$ & $8 \times 12 \times 2 m$ \\
\hline Unladen/start mass & $1.36 / 2.6 \mathrm{~kg}$ & $512 / 1020 \mathrm{~kg}$ \\
\hline The length of the flight & $25 \mathrm{~min}$ & $24-40 \mathrm{~h}$ \\
\hline Drive type / kind & Electric / Propeller & Diesel/Propeller \\
\hline Type of engine & Four electrical engines & $\begin{array}{l}\text { Four pistons engine Rotax } \\
\qquad 914(115 \quad \text { KM) }\end{array}$ \\
\hline Range & $0.7-1 \mathrm{~km}$ & $726 \mathrm{~km}$ \\
\hline Maximum speed & $54 \mathrm{~km} / \mathrm{h}$ & $217 \mathrm{~km} / \mathrm{h}$ \\
\hline The length of the runway & $0 \mathrm{~m}$ (vertical takeoff ) & $1500 \mathrm{~m}$ \\
\hline Crew & 1 person & 2-3 persons \\
\hline Price & ok. $800 \$$ & $4 \mathrm{~m} \ln \$ / 20 \mathrm{~m} \ln \$^{1}$ \\
\hline \multicolumn{3}{|c|}{$\begin{array}{l}\text { cost of } 1 \text { drone/cost of system ( } 4 \text { planes, ground control station, satellite dish } \\
\text { with accessories ) }\end{array}$} \\
\hline
\end{tabular}

Table 1: Comparison of the drones.

vehicles with a maximum take-off weight not more than $25 \mathrm{~kg}$ used exclusively for operations in sight". According to the Act:

1. In the case of a drone with a weight not exceeding $25 \mathrm{~kg}$, it is possible to conduct recreational flights and sports in sight of the operator. To perform such flights do not need a license, permit or insurance.

2. To perform commercial flights of drones not exceeding a mass 25 $\mathrm{kg}$ in sight, it is necessary to have a qualification certificate provider, medical tests flights and civil liability insurance.

3. Flights ships weighing over $25 \mathrm{~kg}$ must be reported to the CAO in order to obtain permission for flights.

4. Flights out of sight of the pilot can only take place in specially separated zones.

5. The law in other countries differs greatly from Polish. In the UK, are permitted the flights:

6. Drones weighing up to $20 \mathrm{~kg}$,

7. At a distance of not less than $150 \mathrm{~m}$ from cities, population centers and $30 \mathrm{~m}$ from the people,

8. With the subscription of OC insurance,

9. In the case of commercial flights the registration, the consent and release the pilot is necessary,

10. Out of sight only in certain areas.

In the United States, the following provisions shall apply:

1. It is possible to perform flights only after receiving a permit issued by the local aviation authorities,

2. Special facilitations in the granting of licenses are entitled to services such as fire, police, and scientific community,

3. To carry out commercial flights is impossible.

In the near future it can be expected, that the Aviation Law will be adapted to the current state of technology. For the companies interested in commercial use of UAVs the flights out of sight (with the fulfillment of additional conditions) will be very important. (Figures 3 and 4)

\section{Posibilities of using the drones}

Unmanned units are the ideal devices to patrol large areas, so they can be used to protect property and the protection of state borders. They can also perform aerial photographs used for geodesy, archaeological, advertising purposes etc. With its small dimensions and high maneuverability they can operate the flights between obstacles, buildings, and even are able to fly to rooms, through the open gates, windows and doors. Models equipped with thermal and night vision cameras (using the infrared active or reinforcing starlight) can be used as prospecting machine in rescue operations, with a daily patrolling of the chosen area and can operate round the clock above the woody areas [20-25]. They transmit an image in a real time allowing on an immediate reaction of relevant services in case of emergency, an accident or a crisis situation requiring intervention. They can be used by the following services, industry and companies:

\section{a) Fire brigade:}

1. Vision support in actions of fighting forest fires, of flood, road, rail and air disasters

2. Thermal imaging the directions of conducting of fires,

3. Thermal detection of fire sources,

4. Tracking and monitoring the sources of pollution,

5. General support of the movable operating position/command.

b) Police:

1. Communication disasters service,

2. Patrolling a designated area,

3. Traffic congestion documentation and traffic jams,

4. Operation and monitoring of mass events,

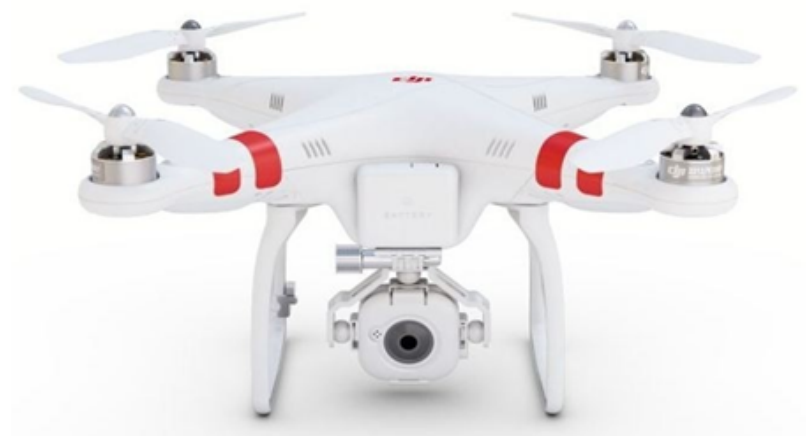

Figure 3: DJI PhantomVision 2.

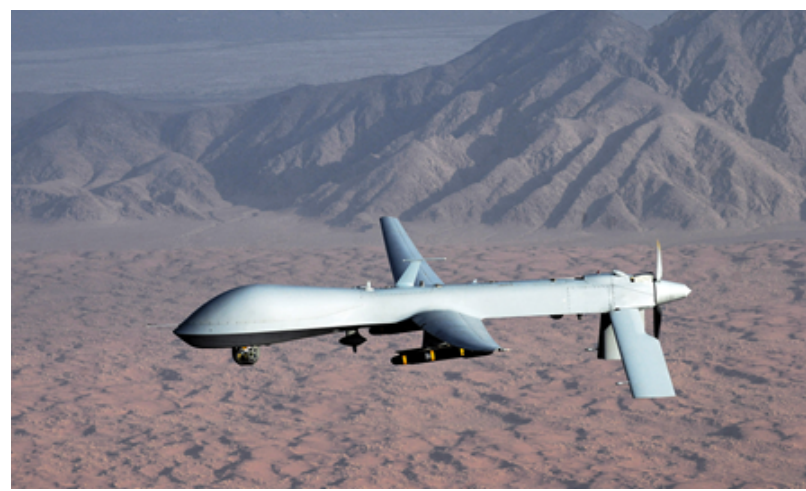

Figure 4: $M Q-1$ Predator 
5. A support for pursuit actions, searching and other police actions,

6. Obtaining the evidence.

c) Border guards:

1. Monitoring the border areas,

2. Air supporting of control traffic border,

3. Fast visualization of the area and mapping,

4. Detection and monitoring of pollution sources objects, land and water border,

5. Tracking moving targets.

d) Army:

1. Reconnaissance and surveillance area,

2. Direct support for fighting and training tasks,

3. Conducting the shares of intelligence,

4. Tracking a moving target,

5. The fight against terrorism.

\section{e) Energetic and chemical industry:}

1. Monitoring, diagnostics and analytics of level gases emission, fumes and other harmful or undesirable substances,

2. Thermal detection of fire sources,

3. Monitoring of production, technology and logistic processes,

4. Control of infrastructure of the determined area.

\section{f) Geodesy companies:}

1. Fast visualization and control of area,

2. Mapping.

g) Advertising Businesses:

1. Spots,

2. Photos I advertising films,

3. Promotional materials.

4. Drones have also a bigger use in delivering shipments.

\section{Risks associated with the use of drones}

The use of drones on a large scale entails a high risk. The main danger is the fall of a drone from a great height, which may be due to:

1. Discharge of the battery,

2. Damage caused by weather conditions (low air temperature, precipitation),

3. Hitting in an obstacle (tree, building, high-voltage line).

These risks can be predicted; therefore the action should be taken to prevent their uprising. The battery status and other telemetry data, including temperature can be controlled remotely by the system. In case of exceeding the one of the parameters the alarm should be launched. This will allow take the action, such as emergency recall the drone to a branch. However, the sensors and software that based on the flight path and on the detected obstacles continuously update the route are responsible for the avoidance of obstacles [26-30]. A serious threat to the drone, due to its value is the people. It can be stolen. In this situation, it may be helpful the localization function and recognizing the situation. Change of the machine course can indicate about the theft. At this case, the drone can begin to take pictures using cameras (sensors) and give a beep deterrent the thief and focusing attention of witnesses [4].

A very important risks associated with the extensive use of civilian drones is related with privacy. These devices have the ability of following for the tracked object and to observe it from many different perspectives. They can be equipped with cameras, night vision devices and various sensors, facilitating snooping. While their wide using by municipal services (including the police) to control the civilian population, could pose a serious danger to human rights. Potential risks associated with the widespread use of drones require the use of complex solutions and the introduction of deliberate regulation aiming at effective protection of citizens' privacy [31-35].

\section{Summary}

Summing, limited use of drones is largely related to the short time of flight, associating with the discharging of the battery powering it and the necessity of recharging. Undoubtedly a big obstacle in the use of drones is mentioned earlier risk of privacy and the rights of citizens. Currently a lot of projects related to the development of power are conducted. One of them is a project of the battery of graphene, which is run by California Lithium Battery. It distinguishes with its high-speed charging, biodegradable and lightness. Another example is the use of pure lithium anodes, which may result in a fourfold increase in battery capacity maintaining the same size and weight [36-39]. You can also consider the use of internal combustion engines as main-propelling the propellers or auxiliary to charge the batteries on the fly. An alternative to the lithium polymer accumulators is the power of drones by fuel cells. In this type of cells electrochemically active substances taking part in the electrode processes are supplied from the outside to the cell and the reaction products are taken to the outside [40]. Therefore the fuel cell works as long as there is provided the fuel (typically hydrogen) and an oxidant (usually oxygen from air). The process of energy conversion overlaps in one stage (direct conversion) and leads to the production of electricity, waste heat and water. The fuel cells system weighs above 3.5 times less than the battery lithium-ion cells with similar parameters. Due to the much more favorable parameters of energy density the attempts are carried out to replace previously used cells (eg. of lithium polymer) with fuel cells [6]. Due to the fact that in unmanned flying apparatuses lengthening of flight time is a critical factor in many cases, there are made the attempts to use fuel cells.

\section{References}

1. Lum CW, Gauksheim K, Deseure C, Vagners J, McGeer T (2011) Assessing and estimating risk of operating unmanned aerial systems in populated areas. In Proceedings of the 11th AIAA Aviation Technology, Integration, and Operations (ATIO) Conference. Virginia Beach.

2. Scheding S, Finn A (2010) Developments and challenges for autonomous unmanned vehicles: A compendium s.1. Springer Sci \& Business 9.

3. Zain M, Hussin AK, Ganraj D (2001) An ultralight helicopter for rice farmers. Universiti Teknologi MARA.

4. Hejduk M (2015) The use of unmanned aerial vehicles - drones supply courier Thesis Inzynierska. Wroclaw.

5. Piotrowski P, Witkowski T, Piotrowski R (2015) Unmanned remote-controlled flying unit. Measurement Automation and Robotics 19: 49-55.

6. Bogusz P, Korkosz M, Wygonik P, Dudek M, Lis B (2015) Analysis of the impact of a supply source for the properties brushless DC motor with permanent magnets designed to drive a flying unmanned camera. Overview Electrotechnical 5 
Citation: Kardasz P, Doskocz J, Hejduk M, Wiejkut P, Zarzycki H (2016) Drones and Possibilities of Their Using. J Civil Environ Eng 6: 233. doi:10.4172/2165-784X.1000233

Page 7 of 7

7. Unmanned Aerial Vehicles in Logistics (2014) A DHL perspective on implications and use cases for the logistics industry.

8. Alberstadt R (2014) Drones under International Law. Open J Political Sci 4.

9. Bardley TH, Moffitt BA, Fuller TF, Mavris D, Parekh D (2013) Design studies for hydrogen fuel cell powered unmanned aerial vehicles. Am Institute of Aeronautics and Astronautics.

10. Catterall C (2013) The hot air ballon book. Chicago Review Press 16.

11. Clothier R, Walker R (2006) Determination and evaluation of UAV safety objectives. In Proceedings 21st International Unmanned Air Vehicle Systems Conference. Bristol, UK.

12. Dalamagkidis K, Valavanis KP, Piegl LA (2008) Evaluating the risk of unmanned aircraft ground impacts. In Proceedings of the 16th Mediterranean Conference on Control and Automation. Ajaccio. France.

13. Floreano D, Wood RJ (2015) Science, technology and the future of small autonomous drones. Nature 521: 460-466.

14. Galvez JP, McCall MK, Napoletano BM, Sarge AW, Koh LP (2014) Small drones for community-based forest monitoring: An assessment of their feasibility and potential in tropical areas. Forests 5: 1481-1507.

15. Hsu J (2015) Cloudy with a chance of drones. Sci Am 313: 20.

16. Jakóbik I (2015) The introduction of drones. Brilliant shots with a bird. Helion S.A.

17. Koh LP, Wich SA (2012) Dawn of drone ecology: low-cost autonomous aerial vehicles for conservation. Tropical Conservation Sci 5: 121-132.

18. Kopczyk M, Osinska-Broniarz M (2013) Batteries - environmentally friendly alternative source of energy for propulsion in the transport system. Exercise Problem Electric Machines 2.

19. Lewandowska A (2009) As the batteries are working, that is, short of redox reactions. Lódz.

20. Loke SW (2015) The internet of flying-things: Opportunities and challenges with airborne fog computing and mobile cloud in the clouds. Internet of Things $\mathrm{J}$.

21. Martin HJ (2013) British American Security Information Council The UK and Armed Drones Key considerations for the future of the UK's programme.

22. Moffitt BA, Bardley TH, Parekh D, Mavirs D (2006) Design and performance validation of a fuel cell unmanned aerial vehicle. Am Institute of Aeronautics and Astronautics.

23. Murrow HN, Eckstrom CV (1979) Drones for Aerodynamic and Structural Testing (DAST) - A Status Report 16: 521-526.
24. Myose RY, Strohl RJ (2014) Uninhabited aerial vehicle (UAV). Engineering \& Materials.

25. Ogden LA (2013) Drone Ecology. BioSci 63: 776.

26. Puttock AK, Cunliffe AM, Anderson K, Brazier RE (2015) Aerial photography collected with a multirotor drone reveals impact of Eurasian beaver reintroduction on ecosystem structure. J Unmanned Vehicle Systems 3: 123130

27. Rango A, Laliberte A, Steele C, Herrick JE, Bestelmeyer B (2006) Using unmanned aerial vehicles for rangelands: current applications and future potentials. Environ Practice 8: 159-168.

28. Rhoads GD, Wagner NA, Taylor B, Keen D (2010) Design and flight test results for a 24 hour fuel cell unmanned aerial vehicle. 5th Annual International Energy Conversion Engineering Conference, AIAA 2010-6690.

29. Schlag C (2013) The new privacy battle: How to expending use of drones continuous to erode our concept of privacy and privacy rights. J Technol Law \& Policy 13

30. Topalov AV (2009) Unmanned aerial vehicles and aircraft systems. Int $J$ Advanced Robotic Systems.

31. Civilian use of drones in the EU (2014-1015) European Union Committee 7th Report of Session.

32. Future challenges in drone geopolitics, Article 4 Drones (2014) The American Controversy. J Strategic Security 7.

33. Ken Pearson (2009) Jadoo fuel cells powers Mako unmanned aerial vehicle Fuel Cells Bulletin 4.

34. Record flight UAV using Protonex fuel cell system (2009) Fuel Cells Bulletin 4.

35. Unmanned Aerial Systems Circular (2011) International Civil Aviation Organization (CAO).

36. Technical guidelines for batteries and accumulators in terms of their being subject to the provisions of the Act of 24 April 2009. On batteries and accumulators (D.U. Nr. 79, poz.666).

37. http://www.mvb.pl/files/mvb/BSP_-_nowy_folder_201310.pdf

38. http://rightbattery.com/tag/alkaline-batteries-2/

39. Lapena-Rey N, Mosquera J, Bataller E, Otri F (2008) Environmentally friendly power sources for aerospace applications. J Power Sources 181: 353-362.

40. Lapena-Rey N, Mosquera J, Bataller E, Orti F (2010) First fuel-cell manned aircraft. J Aircraft 47: 1825-1835. 